\title{
Pemanfaatan Media Sosial Sebagai Sarana Promosi Perpustakaan
}

\author{
Serly Maretno, Marlini \\ ${ }_{1,2}$ Program Studi Perpustakaan dan Ilmu Informasi Fakultas Bahasa dan Seni, Universitas \\ Negeri Padang \\ Jl. Prof. Dr. Hamka, Air Tawar Bar., Kec. Padang Utara, Kota Padang, Sumatera Barat 25171 \\ e-mail: serlymaretno@gmail.com
}

\begin{abstract}
Introduction. Library promotion is a process to introduce all activities, services, and collections of library materials in the library to the public. The purpose of library promotion is so that people can know and understand all activities, services, and collections of library materials available in the library. One of the means that can be used as a media for library promotion is to use social media, which when compared to the use of conventional media or other media, social media is considered superior and brings many benefits to the library that carries out the promotion.

Data Collection Methods. The research uses literature study method. Data collection is done by taxing, reading, and recording existing data in literature, such as articles or journals that are guaranteed to the fidelity.

Results and Discussion. Based on the research that has been done, the use of social media as a means of library promotion brings many benefits and advantages when compared to the use of conventional media. With the use of social media as a means of library promotion, the process of library promotion can be global, fast, cheap, and open to a more intense interaction between librarians and users.
\end{abstract}

Conclusion. The study uses the literature study method to obtain information about the use of social media as a means of library promotion.

Keywords: social media; library promotion; benefits

\begin{abstract}
ABSTRAK
Pendahuluan. Promosi perpustakaan merupakan suatu proses untuk meperkenalkan seluruh kegiatan, layanan, dan koleksi bahan pustaka yang ada di perpustakaan kepada masyarakat. Tujuan promosi perpustakaan adalah agar masyarakat dapat mengetahui dan memahami seluruh kegiatan, layanan, dan koleksi bahan pustaka yang tersedia di perpustakaan. Salah satu sarana yang dapat digunakan sebagai media promosi perpustakaan adalah dengan memanfaatkan media sosial, yang apabila dibandingkan dengan penggunaan media konvensional atau media lainnya, media sosial dinilai lebih unggul dan banyak mendatangkan manfaat pada perpustakaan yang melalukan promosi tersebut.

Metode Penelitian. Penelitian ini menggunakan metode studi literatur. Pengumpulan datanya dilakukan dengan cara mengambil, membaca, dan mencatat data yang ada pada bahan literatur seperti artikel atau jurnal yang terjamin kefalidannya.

Hasil dan Pembahasan. Berdasarkan penelitian yang telah dilakukan, pemanfaatan media sosial sebagai sarana promosi perpustakaan mendatangkan banyak manfaat dan kelebihan apabila dibandingkan dengan penggunaan media konvensional. Dengan digunakannya media sosial sebagai sarana promosi perpustakaan, maka proses promosi perpustakaan dapat
\end{abstract}


berlangsung secara global, cepat, murah, dan membuka interaksi yang lebih intens antara pustakawan dengan pengguna.

Kesimpulan dan Saran. Penelitian ini menggunakan metode studi literatur untuk mendapatkan informasi mengenai pemanfaatan media sosial sebagai sarana promosi perpustakaan.

Kata Kunci: media sosial; promosi perpustakaan; manfaat

\section{A. PENDAHULUAN}

Kegiatan promosi perpustakaan menjadi salah satu cara untuk mengkomunikasikan dan mengenalkan sebuah perpustakaan beserta manfaat, fasilitas, maupun sumber-sumber informasi yang tersedia di dalamnya kepada para pengguna perpustakaan. Selama ini, perpustakaan masih sering dianggap sebagai sebuah ruang atau gedung kuno, berdebu, dan membosankan yang ditambah pula dengan adanya petugas perpustakaan yang terlihat kutu buku dan galak. Dari pemikiran tersebut membuat banyak masyarakat maupun civitas akademik enggan untuk menginjakkan kakinya di perpustakaan. Adanya kegiatan promosi perpustakaan, menjadi sebuah sumber yang memiliki peranan penting dalam hal mengenalkan seluk beluk perpustakaan. Kegiatan promosi ini sifatnya mengajak masyarakat untuk bisa mengetahui secara mendalam dan lebih dekat lagi terhadap perpustakaan yang dipromosikan. Dengan hal tersebut, diharapkan masyarakat tidak lagi berpikir secara negatif terhadap perpustakaan, dikarenakan mereka sudah mengenal dan paham terhadap apa yang ada di perpustakaan. Dimulai dari fasilitas, layanan perpustakaan yang disediakan, koleksi bahan pustaka, dan lain sebagainya.

Menurut Ritzer (dalam Ifonilla Yenianti, 2019:226), karakteristik pengguna perpustakaan di zaman dahulu (pra industri) dengan zaman sekarang (pasca industri) ini sangat jauh berbeda. Perkembangan teknologi, informasi, dan komunikasi menjadi salah satu peyebab perubahan sosial di masyarakat. Pesatnya perkembangan TIK tersebut juga diiringi dengan adanya perkembangan jaringan internet dan media sosial di dalamnya. Adanya perkembangan TIK, membuat perpustakaan mau tidak mau harus mengikuti dan menyesuaikan diri terhadap arus perkembangan teknologi dan informasi, agar perpustakaan tersebut tidak ditinggalkan oleh penggunanya.

Sekarang ini, telah banyak perpustakaan yang memanfaatkan media sosial sebagai salah satu media promosi pada perpustakaan. Hal ini disebabkan karena hampir seluruh masyarakat di belahan dunia menggunakan media sosial sebagai media berkomunikasi dan memperoleh informasi yang dibutuhkan. Seperti data yang ditunjukkan oleh Hoosuite (We Are Social) pada tahun 2020, yang menyebutkan dari total penduduk dunia sebanyak 7.750 milyar penduduk, terdapat 3.800 milyar penduduk yang menggunakan secara aktif media sosial. Sedangkan pengguna internet sebanyak 4.540 milyar penduduk dan pengguna mobile unik sebanyak 5.190 milyar penduduk. Indonesia sendiri dengan jumlah populasi penduduk sebanyak 272,1 juta jiwa, terdapat 
160 juta jiwa yang menggunakan media sosial aktif, 175,4 juta jiwa yang menggunakan internet, dan 338,2 juta jiwa yang menggunakan mobile unik. Dari total seluruh penduduk di Indonesia, terdapat $88 \%$ pengguna Youtube, $84 \%$ pengguna Whatsapp, 82\% pengguna Facebook, dan 79\% pengguna Instragram (Andi Dwi Ariyanto, 2020). Dari data-data tersebut, dapat disimpulkan bahwasanya Indonesia termasuk ke dalam salah satu negara pengguna internet dan sosial media terbesar di dunia. Adapun pustakawan harus berpandai-pandai dalam melihat peluang tersebut untuk dapat melakukan promosi perpustakaan kepada masyarakat melalui pemanfaatan media sosial.

Penelitian ini mengkaji tentang pemanfaatan media sosial sebagai sarana promosi perpustakaan. Adapun tujuan dari penelitian ini yaitu untuk mengetahui maksud dari media sosial dan promosi perpustakaan, jenis-jenis media sosial, manfaat media sosial, kelebihan media sosial, sarana-sarana promosi, dan bagaimana cara pustakawan melakukan promosi perpustakaan via media sosial.

\section{B. TINJAUAN PUSTAKA}

\section{Media Sosial}

Media sosial tersusun dari dua kata, yaitu media dan sosial. Arti dari media adalah alat komunikasi atau alat perantara, sedangkan sosial adalah sebuah aksi yang dilakukan oleh setiap individu dalam memberikan kontribusinya kepada masyarakat. Jadi, maksud dari media sosial adalah suatu alat komunikasi yang digunakan oleh seseorang dalam melakukan proses sosialnya di tengah masyarakat (Mulawarman \& Aldila Dyas Nurfitri, 2017:37).

\section{Promosi Perpustakaan}

Promosi perpustakaan merupakan suatu proses untuk memperkenalkan seluruh kegiatan yang ada di perpustakaan, layanan yang tersedia di dalamnya, dan koleksi atau sumber-sumber informasi yang ada di perpustakaan kepada masyarakat umum. Dengan diadakannya promosi perpustakaan ini, diharapkan masyarakat dapat mengenal dan memanfaatkan secara maksimal produk dan jasa yang ada di perpustakaan tersebut. Di era sekarang ini, promosi perpustakaan dapat berjalan lebih efektif dengan cara memanfaatkan media sosial, seperti facebook, instagram, twitter, dan lainnya (Nadia Amelia Qurrota A’yunin, 2018:51).

\section{METODE PENELITIAN}

Metode yang digunakan dalam penelitian ini adalah studi literatur. Studi literatur merupakan serangkaian kegiatan berkaitan dengan metode pengumpulan data, membaca dan mencatat, serta mengelola bahan penelitian dengan cara menelaah 15 jurnal terkait dengan pemanfaatan media sosial sebagai sarana promosi perpustakaan. 


\section{HASIL DAN PEMBAHASAN}

\section{Media Sosial}

Istilah media sosial terangkai dari dua kata yang berbeda, yaitu "media" dan "sosial". Media dapat diartikan sebagai sebuah sarana, penghubung, atau alat yang digunakan untuk menyampaikan pesan dari si komunikator (pengirim pesan) kepada banyak orang. Sedangkan sosial adalah suatu hal yang berhubungan dengan masyarakat luas atau sebuah cara untuk berinteraksi antara satu orang dengan orang lainnya. Rustiana (2018:20) mendefinisikan media sosial sebagai sebuah media jejaring sosial berupa platform digital yang dapat menyebarkan informasi berupa teks, audio, gambar, video, maupun audio-video, yang berfungsi sebagai sarana komunikasi, kolaborasi, dan interaksi antara satu dengan yang lainnya. Sependapat dengan hal tersebut, Budiman, Ernita Arif, \& Elva Ronaning Roem (2019) mendefinisikan media sosial sebagai sebuah media online yang oleh penggunanya dimanfaatkan untuk ikut berperan aktif dan saling bertukar informasi, dengan ciri penyebarannya dari satu orang ke banyak orang dan banyak orang ke banyak orang lainnya. Sedangkan menurut Andreas Kaplan dan Michael Haenlein (dalam Jiyanto dan Muhammad Miftah, 2017: 203), media sosial merupakan sekelompok aplikasi yang berbasis jaringan internet, yang mana didirikan di atas teknologi web 2.0 dan dasar ideologi, serta memungkinkan penggunanya untuk menciptakan dan berbagi konten. Dari definisi-definisi tersebut dapat disimpulkan bahwasanya media sosial merupakan sebuah media online yang memfasilitasi penggunanya untuk dapat membuat, menciptakan dan membagikan banyak konten (gambar, foto, audio, video, dll) kepada banyak orang.

Pengguna media sosial bisa dengan sangat mudah membuat, menciptakan, ataupun membagikan isi yang meliputi blog, forum, wikis, jejaring sosial, dunia virtual, maupun konten kepada ribuan bahkan jutaan orang di luar sana. Media sosial memberikan kesempatan kepada para penggunanya untuk bisa saling berinteraksi sosial dengan menggunakan teknologi berbasis web, sehingga komunikasi yang terjalin diantaranya menjadi diolog dua arah yang interaktif. Hadirnya media sosial menaklukan dan menghapus batasan-batasan ruang dan waktu, dimana semua orang dapat saling berkomunikasi tanpa mempedulikan tempat dan waktunya. Tidak dapat dihindari, media sosial ini memberikan banyak sekali pengaruh pada kehidupan sehari-hari seseorang, seperti pada pendidikan, politik, ekonomi, bisnis, sosial, dan lain sebagainya.

Indonesia sendiri, tercatat sebagai salah satu negara dengan pengguna media sosial terbesar di dunia. Khususnya pada kalangan remaja, media sosial menjadi sebuah candu yang tidak bisa dipisahkan selama 24 jam non-stop. Beberapa media sosial yang banyak digunakan oleh mereka, diantaranya youtube, instagram, facebook, twitter, line, whatapps, dan masih banyak lagi lainnya. 
Jadi, tak heran perpustakaan-perpustakaan sekarang ini saling membenahi dirinya masing-masing untuk terus mengikuti arus perkembangan teknologi. Salah satunya yaitu dengan memanfaatkan penggunaan media sosial sebagai media promosi perpustakaan yang lebih efektif dan efisien.

\section{Jenis-Jenis Media Sosial}

Kaplan dan Haenlein (dalam Arief Gunawan, 2017: 51) menggolongkan media sosial ke dalam enam jenis, yaitu:

\section{a. Blog dan Microblog}

Merupakan sebuah website yang dapat digunakan oleh seseorang atau sekelompok orang untuk memasang tulisan. Pengguna tersebut dapat secara bebas mengungkapkan segala hal dalam blog tersebut, seperti kritikan, pengalaman, maupun pernyataan. Dalam blog tersebut tersedia ruang bagi pengunjung untuk membaca dan saling berbalas komentar. Contohnya seperti twitter.

\section{b. Virtual Game World}

Melalui dunia virtual ini, penggunanya dapat merasakan keadaan yang ada secara nyata, dikarenakan para pengguna situs ini dapat saling berinteraksi satu sama lain. Sehingga seakan-akan mereka berada dalam dunia nyata, yang pada kenyataanya mereka hanya berada di dunia maya (internet) yang sedang mengreplikasikan lingkungan 3 dimensi. Contohnya seperti game online.

\section{c. Konten}

Pengguna website ini dapat dengan mudah memasang dan membagikan konten-konten multimedia yang dimiliki, seperti foto, gambar, video, ebook, dan lain sebagainya. Selanjutnya, konten-konten tersebut nantinya akan dibagikan atau disebarkan kepada banyak orang. Contohnya seperti youtube.

\section{d. Virtual Social World}

Pengguna dunia virtual ini akan merasa bahwa dirinya tengah hidup di dunia virtual dan bisa saling berinteraksi dengan orang lain. Berbeda dengan virtual game world, virtual social world ini lebih bebas dan mengarah kepada kehidupan. Contohnya seperti second life.

\section{e. Proyek Kolaborasi}

Bagi pengunjung situs ini yang sudah terdaftar sebagai anggota atau pengguna resmi, mereka diizinkan untuk menambahkan, mengganti, maupun membuang konten-konten yang termuat di dalamnya dengan menggunakan sumber yang baru dan lebih berkualitas. Contohnya seperti Wikipedia. 


\section{f. Situs Jejaring Sosial}

Pengguna jejaring sosial memperoleh izin untuk bisa terhubung (terkoneksi) dengan cara si pengguna membuat informasi yang sifatnya pribadi, kelompok, maupun sosial, sehingga dapat diakses atau dapat saling terhubung dengan dengan orang-orang di luaran sana. Contoh jejaring sosial diantaranya facebook dan instagram.

\section{Manfaat Media Sosial}

Berikut ini adalah beberapa manfaat yang diperoleh dari adanya penggunaan media sosial.

\section{a. Mudah Memperoleh Informasi}

Hadirnya media sosial memudahkan kita untuk bisa mendapatkan informasi terbaru yang sifatnya umum maupun khusus. Sebelumnya untuk bisa mendapatkan informasi terbaru, biasanya kita mendapatkannya dengan membaca koran, majalah, atau lainnya terlebih dahulu. Namun pesatnya teknologi sekarang ini, membuat kita cukup duduk manis saja di rumah, maka akan sangat dengan mudah kita mendapatkan informasi terbaru yang tengah kita butuhkan.

\section{b. Berbisnis}

Tak sedikit orang yang memanfaatkan media sosial sebagai ladang tempat penghasil uang. Ada banyak wirausahawan yang menggunakan media sosial sebagai salah satu tempat yang efektif dan strategis untuk mempromosikan barang dan jasa (bisnis online) yang ditawarkan. Tak jarang pula, media sosial melahirkan banyak selebgram dan youtuber yang menyajikan beragam konten dan disukai oleh banyak orang.

\section{c. Berkomunikasi Tanpa Batasan Ruang dan Waktu}

Adanya media sosial memudahkan kita untuk bisa saling berkomunikasi dengan orang tua, keluarga, teman, rekan kerja, kolega, dan lainnya tanpa batasan ruang dan waktu, tidak peduli kita sekarang berada dimana dan di jam berapa.

\section{d. Sebagai Media Pembelajaran}

Di tengah situasi pandemi Covid-19 sekarang ini, media sosial menjadi salah satu solusi dalam menjalankan aktivitas pembelajaran. Para tenaga pengajar tidak perlu lagi melaksanakan kegiatan pembelajaran di sekolah atau kampus (tatap muka) yang berpotensi sebagai tempat penyebaran Covid-19. Tenaga pengajar hanya perlu membagikan konten apapun (modul, materi pelajaran, e-book, tugas mandiri, quiz, soal ujian, video pembelajaran, dll) kepada para pelajar. Para pelajar juga dapat dengan mudah mengunduh berbagai materi pembelajaran guna membantu dalam penyelesaian tugas atau lain sebagainya. 


\section{e. Sebagai Sarana Hiburan}

Disaat kita tengah dilanda bosan karena tugas atau pekerjaan yang menumpuk, kita sering kali memanfaatkan media sosial untuk menghibur diri kita sendiri. Di media sosial, kita menemukan banyak hal baru dan menarik, sehingga mampu mengembalikan suasana hati kita. Contohnya seperti menonton youtube, bermain facebook dan instagram, menulis di blog, dan lain sebagainya.

\section{Kelebihan Media Sosial}

Terdapat beberapa kelebihan yang kita dapatkan dari penggunaan media sosial, namun tidak dimiliki oleh media konvensional, yaitu sebagai berikut.

a. Penggunaan media sosial dapat menjangkau secara luas dan global. Media konvensional juga bisa saja menjangkau secara global, namun media konvensional memerlukan waktu lebih lama dibandingkan dengan media sosial, serta membutuhkan biaya yang tidak sedikit. Sedangkan media sosial sendiri, siapapun bisa mengkomunikasikan dan menyebarkan informasi yang dimiliki secara cepat, tanpa adanya hambatan terhadap ruang (letak geografis).

b. Penggunaan media sosial menciptakan hubungan yang lebih intens. Media konvensional hanya bisa melakukan komunikasi dalam satu arah saja, sedangkan media sosial dapat membangun komunikasi dalam dua arah dan lebih intens. Media sosial memberikan kesempatan lebih kepada para penggunanya untuk bisa saling berinteraksi dengan keluarga, teman, kerabat, mitra, relasi, rekan, pelanggan, dan lain-lain. Selain itu, media sosial juga membantu pengguna dalam membangun hubungan timbal balik secara langsung dengan orang-orang tersebut.

c. Penggunaan media sosial cepat, mudah, dan sederhana. Pengguna media sosial tidak harus memiliki pengetahuan atau ahli di bidang teknologi informasi, karena hampir semua orang dapat menggunakan media sosial. Berbeda dengan media konvensional yang membutuhkan keterampilan khusus atau di bidang tertentu. Penggunaan media sosial juga sangat mudah dan sederhana, dimana media sosial hanya membutuhkan smartphone, tablet, laptop, ataupun komputer yang dilengkapi dengan adanya jaringan internet.

d. Dengan media sosial, berbagi informasi berlangsung lebih cepat. Berbeda dengan media konvensional yang membutuhkan waktu yang cukup lama dalam berbagi informasi, media sosial justru membuat para penggunanya dapat saling berbagi informasi jauh lebih cepat, real time. Hanya sekali 'klik' saja, informasi yang kita butuhkan sudah ada di depan mata (Endang Fatmawati, 2017: 4). 


\section{Promosi Perpustakaan}

Promosi perpustakaan dapat dikatakan sebagai susunan kegiatan yang bermula dari perencanaan, proses, hingga penyelesaian, yang memiliki tujuan agar masyarakat dapat mengetahui fasilitas, koleksi bahan pustaka, layanan perpustakaan, dan kegiatan yang tersedia di perpustakaan tersebut. Promosi perpustakaan bertujuan untuk memperkenalkan fungsi dan manfaat perpustakaan kepada masyarakat, agar masyarakat dapat mengetahui layanan apa saja yang tersedia di perpustakaan sehingga masyarakat tertarik untuk datang dan memanfaatkan koleksi yang ada. Media-media promosi yang biasa digunakan, seperti media cetak, ceramah, media elektronik, pameran, dan lain sebagainya (Hary Supriyatno, 2019: 37-38).

Promosi menjadi salah satu hal penting yang harus dilakukan di perpustakaan. Promosi menjadi sebuah 'jembatan' komunikasi antara pihak perpustakaan dengan masyarakat. Salah satu hal yang menjadi kunci keberhasilan dari sebuah perpustakaan adalah pada tingkat kunjungan dan pemanfaatkan koleksi bahan pustaka oleh para pengguna (Hariyah \& Agus Triyanto, 2018: 34). Promosi perpustakaan adalah sebuah aktivitas untuk memperkenalkan atau mempromosikan perpustakaan kepada masyarakat luas mengenai hal-hal apa saja yang ada di perpustakaan, seperti kegiatan, fasilitas, koleksi bahan pustaka, layanan, manfaat, dengan menggunakan media dan cara yang sifatnya mengajak. Promosi perpustakaan diadakan untuk memperkenalkan perpustakaan yang bersangkutan secara lebih luas dan dalam kepada masyarakat. Selain itu, promosi perpustakaan juga bertujuan untuk meningkatkan minat baca masyarakat dan mendorong terhadap penggunaan koleksi bahan pustaka yang ada di perpustakaan secara maksimal.

Oleh UNISCO, Indonesia disebut berada di urutan kedua dari bawah sebagai negara dengan minat baca yang rendah, yaitu sebesar 0,001\% (Evita Devega, 2017). Untuk itulah kegiatan promosi perpustakaan ini diharapkan menjadi salah satu cara untuk membantu meningkatkan minat baca masyarakat Indonesia. Adanya promosi perpustakaan juga dapat membantu dalam memperkenalkan segala fasilitas, layanan, kegiatan, dan koleksi bahan pustaka apa-apa saja yang ada di perpustakaan. Dengan mengetahui hal tersebut, diharapkan pengguna tidak lagi enggan atau malas menginjakkan kakinya di perpustakaan, serta membuang jauh-jauh pikiran buruk mengenai perpustakaan.

\section{Sarana-Sarana Promosi}

Ada banyak sekali media yang dapat digunakan sebagai sarana promosi. Menurut Basmi Adam (2015: 35-36), sarana promosi dapat dengan menggunakan media elektronik (seperti televisi, internet, dan radio), media cetak (surat kabar, majalah, dan brosur), pameran, poster, news letter, pembatas buku, 
terbitan khusus perpustakaan, ceramah, seminar, dan berbagai kegiatan lainnya di perpustakaan.

\section{a. Media Elektronik}

1) Televisi, adalah sebuah media yang dilengkapi dengan audio visual, dan sangat efektif apabila digunakan untuk mempromosikan sebuah barang atau jasa dikarenkana jangkauannya yang luas.

2) Internet, penggunaan website yang menarik oleh sebuah perpustakaan yang dapat mengajak banyak pengunjung untuk datang ke perpustakaan. Melalui website tersebut pengguna dapat mengetahui informasi yang berkaitan dengan perpustakaan tersebut, seperti layanannya, koleksi pustaka, cara peminjaman atau pengembalian, dan lain sebagainya.

3) Radio, perpustakaan dapat menggunakan radio sebagai sarana promosi perpustakaan, dimana radio sendiri merupakan media audio yang isinya bertumpu pada informasi insidental.

\section{b. Media Cetak}

1) Surat Kabar, dapat digunakan untuk mendisplaikan buku terbaru atau yang tengah menjadi best seller di pasaran, dan buku-buku tersebut sudah dimiliki oleh perpustakaan. Dengan demikian, para pengguna akan banyak datang ke perpustakaan untuk meminjamnya atau hanya sekedar membaca di tempat.

2) Majalah, melalui majalah ini, perpustakaan dapat menampilkan sebuah profil singkat mengenai perpustakaan yang bersangkutan, yang dilengkapi kelebihan atau keunikan yang tidak dimiliki oleh perpustakaan lainnya. Sehingga hal tersebut dapat menarik pengguna untuk datang ke perpustakaan.

3) Brosur, media promosi yang efektif apabila digunakan untuk memberikan informasi yang memiliki sifat beralur.

c. Pameran, menjadi salah satu sarana promosi yang bagus untuk mengajak banyak pengguna datang ke perpustakaan. Semakin banyak melakukan pameran, maka perpustakaan akan semakin banyak dikenal oleh masyarakat.

d. Poster, media promosi yang didalamnya memuat tulisan dan gambar yang menarik. Tujuan dari poster ini adalah untuk menarik perhatian kepada setiap orang yang melewati tempat poster tersebut dipasang, seperti di tiang listrik, dinding, dan lain-lain.

e. News Letter, memberikan informasi yang khusus kepada sejumlah individu secara teratur. Isi dari news letter yaitu mengenai artikel atau berita yang singkat, namun di dalamnya tetap memuat informasi rinci dan singkat mengenai layanan, koleksi, kegiatan, fasilitas, editorial, dan juga dilengkapi dengan gambar-gambar. 
f. Pembatas Buku, digunakan untuk memberikan tanda pembatas pada halaman buku tertentu. Hal tersebut bertujuan agar halaman yang sudah dibaca dan diberi tanda tersebut dapat dibaca kembali untuk di lain waktu.

g. Terbitan Khusus Perpustakaan, berbentuk terbitan yang diterbitkan atau dikeluarkan oleh perpustakaan yang bersangkutan. Misalnya seperti sebuah buku panduan terhadap penggunaan perpustakaan, kalender, dan lain-lain.

h. Ceramah, adalah sebuah kegitan dimana seseorang berbicara di sebuah forum kegiatan tertentu, sedangkan yang lainnya medengarkan dengan khidmat terhadap isi ceramah yang disampaikan. Perpustakaan dapat mempromosikan dirinya melalui media ceramah tersebut.

i. Seminar, sebuah kegiatan yang pelaksanaanya dilakukan sama seperti sebuah ceramah, namun seminar ini jangkauannya lebih luas lagi.

j. Berbagai Kegiatan Lainnya di Perpustakaan, seperti kegiataan bazar, nonton bareng, wisata perpustakaan, perlombaan (seperti berdongeng, baca puisi, cipta puisi, menggambar, mewarnai), dan lain-lain.

\section{Promosi Perpustakaan Via Media Sosial}

Sekarang ini, ada banyak perpustakaan yang menggunakan media sosial sebagai media untuk bisa melakukan promosi kepada masyarakat luas, baik itu mempromosikan koleksi bahan pustaka yang dimiliki, fasilitas yang disediakan, layanan yang tersedia, dan lain sebagainya. Promosi perpustakaan menggunakan media sosial dapat dilakukan dengan proses yang cepat dan murah. Cepat, dikarenakan melalui media sosial, tidak diperlukan proses yang panjang untuk bisa mengunggah dan menyebarkan informasi seputar perpustakaan yang bersangkutan kepada masyarakat luas. Hanya dengan satu 'klik' saja, informasi tersebut telah sampai kepada ribuan orang di luaran sana. Murah, dikarenakan penggunaan media sosial tersebut tidak memerlukan biaya yang besar untuk melakukan promosi perpustakaan yang dapat menarik masyarakat untuk datang ke perpustakaan (Jody Santoso, 2019: 5). Beberapa media sosial yang dapat digunakan oleh perpustakaan, diantaranya seperti whatsapp, instagram, twitter, facebook, dan lain sebagainya.

a. Manfaat promosi perpustakaan melalui sosial media

Promosi perpustakaan yang dilakukan melalui media sosial akan dapat menjangkau lebih luas calon pengguna yang datang berkunjung ke perpustakaan. Dikarenakan media sosial sendiri sifatnya global (mendunia), sehingga informasi yang disampaikan tersebut, akan lebih banyak lagi dibaca dan dilihat oleh orang. Prosesnya pun tidak memakan waktu yang lama dan biaya yang dikeluarkan tidak terlalu besar. Perpustakaan hanya perlu menyediakan seperangkat peralatan komputer 
dan jaringan internet untuk dapat menunjang kegiatan promosi perpustakaan melalui media sosial agar dapat berjalan lancar. Dengan demikian, biaya yang dikeluarkan dapat ditekan dan waktu yang digunakan lebih singkat dibandingkan dengan promosi menggunakan media konvensional. Interaksi yang terjalin antara pihak perpustakaan dengan masyarakat juga lebih intens dan terbuka, dikarenakan tidak adanya batasan ruang dan waktu dalam berinteraksi. Selain itu, juga adanya umpan balik secara langsung yang berjalan lebih cepat dibandingkan dengan pelayanan offline. Pemanfaatan media sosial sebagai media promosi perpustakaan juga menjadi salah satu cara untuk menunjukkan dan meningkatkan citra baik perpustakaan di mata masyarakat. Hal tersebut menjadi sebuah langkah awal transformasi perpustakaan di era digital sekarang, yang menandakan perpustakaan juga ikut berkembang seiring dengan arus perkembangan teknologi. Melihat hal tersebut, masyarakat tidak akan berpikir dua kali untuk datang ke perpustakaan dikarenakan melihat media promosi yang digunakan lebih fresh, kekinian, tidak kuno, dan tidak tertinggal dari teknologi.

b. Strategi promosi perpustakaan melalui sosial media

Meskipun media sosial adalah sesuatu yang umum dan hampir semua orang bisa menggunakannya, namun dalam hal ini pihak perpustakaan tidak bisa menyerahkan tanggung jawab pengelolaan media sosial kepada sembarang orang. Perpustakaan harus benar-benar menyiapkan tenaga kerja (pustakawan) yang memang memiliki keahlian atau kemampuan khusus berkaitan dengan pengelolaan media sosial ini. Kemampuan khusus yang sekiranya harus dimiliki oleh pustakawan, diantaranya mampu mengupload konten atau informasi yang sesuai dengan media sosial yang tengah digunakan; ketanggapan pustakawan dalam berinteraksi dengan pengguna yang diperlukan agar pengguna merasa diberikan pelayanan yang prima oleh pustakawan; pustakawan harus menjaga nama dan citra baik perpustakaan di mata para penggunanya dengan menyajikan dan menyebarkan informasi yang baik, orisinil, dan tidak menyinggung hak cipta; dan lain sebagainya. Dari hal tersebut, sekiranya pihak perpustakaan dapat mengikutsertakan pustakawannya dalam pelatihan ataupun seminar yang membahas topik mengenai penggunaan media sosial di perpustakaan. Selain didukung dari kualifikasi pustakawan yang bekerja, pemanfaatan media sosial sebagai media promosi perpustakaan juga harus mendapat dukungan dari manajemen terkait dengan hal pergeseran dan perubahan pola komunikasi yang terjadi di perpustakaan tersebut. Ketika perpustakaan akhirnya memutuskan untuk melibatkan media sosial sebagai media 
promosi perpustakaan, maka kita harus bersiap menghadapi perubahan budaya organisasi dan komunikasi. Komunikasi yang terjalin akan lebih intens dan terbuka, serta budaya organisasi yang terjadi di perpustakaan, seperti pada jam pelayanan di perpustakaan akan terlihat lebih fleksibel dibandingkan dengan jam layanan dengan sistem konvensional.

c. Kendala promosi perpustakaan melalui sosial media

Meskipun telah memanfaatkan media sosial dan selalu rutin memposting informasi di dalamnya, namun promosi perpustakaan tersebut tidak selalu berjalan baik dan mampu mendapatkan banyak respon/perhatian dari pengguna. Pustakawan perlu memikirkan strategi untuk dapat menarik dan mendapatkan banyak respon dari pengguna. Misalnya, dengan membagikan informasi yang tepat, tidak bertele-tele, dan bernilai; menggunakan tag/keyword yang dapat memudahkan pengguna menemukan konten atau informasi yang diposting; memilih resolusi terbaik dalam memposting video maupun foto; memakai hastag (\#) ketika hendak mengupload informasi di media sosial; memadukan beraneka gambar, warna, maupun tulisan pada setiap kali mengupload informasi, agar pengguna merasa tertarik ketika melihatnya; pustakawan aktif berbalas komentar dengan para pengguna; menggunakan filter pada instagram agar terlihat lebih menarik; memberikan judul dan thumbnail (youtube) yang sesuai dan menarik; dan secara rutin memposting informasi di media sosial, baik dalam bentuk teks, foto, maupun video (Nining Kurniasih, 2016: 7-8).

\section{E. KESIMPULAN}

Media sosial merupakan media online yang terhubung dengan jaringan internet, yang memungkinkan untuk terjadinya interaksi sosial dengan banyak orang dengan membagikan konten, seperti foto, gambar, audio, video, dan lain sebagainya. Masyarakat saat sekarang ini memiliki hasrat penggunaan yang tinggi terhadap media sosial dalam hal memperoleh informasi. Media sosial hadir dengan beragam jenis dan manfaat, serta kelebihan yang tidak akan ditawarkan oleh media konvensional. Salah satunya yaitu perpustakaan, yang memanfaatkan media sosial sebagai media promosi perpustakaan. Salah satu kunci dalam keberhasilan perpustakaan, yaitu terletak pada kunjungan pengguna dan pemanfaatan secara maksimal koleksi bahan pustaka oleh pengguna. Untuk itulah promosi perpustakaan dilakukan guna meningkatkan kedua hal tersebut dan demi mewujudkan keberhasilan perpustakaan sebagai lembaga yang 
menyediakan informasi kepada masyarakat. Kepopuleran media sosial saat sekarang ini harus dimanfaatkan perpustakaan sebagai media promosi yang memudahkan dalam berinteraksi dan menarik pengguna untuk datang ke perpustakaan. Dalam pemanfaatannya tersebut, media sosial harus dikelola dengan baik oleh pustakawan agar manfaat yang diharapkan dari kegiatan promosi perpustakaan tersebut dapat tercapai pula dengan baik. Perpustakaan tidak hanya menyediakan alat (sarana) yang diperlukannya saja, namun juga menyiapkan banyak hal, seperti pada kualifikasi pustakawan yang mengelolanya dan pada dukungan yang diperoleh dari manajemen perpustakaan itu sendiri.

\section{DAFTAR PUSTAKA}

Asdam, Basmi. (2015). Minat Baca dan Promosi Peprustakaan sebagai Sarana Mendekatkan Masyarakat pada Perpustakaan. Jupiter, 14 (1), 32-37.

A’yunin, Nadia Amelia Qurrota. (2018). Promosi Perpustakaan Pusta Studi Asia Tenggara Universitas Gadjah Mada Yogyakarta Melalui Media Sosial. LIBRIA, 10 (1), 48-63.

Budiman, Ernita Arif, \& Elva Ronaning Roem. (2019). Pemanfaatan Media Sosial sebagai Sarana Promosi Perpusda Kabupaten Belitung Timur. Jurnal Ranah Komunikasi, 3 (1), 34-44.

Devega, Evita. (2017). Teknologi Mayarakat Indonesia: Malas Baca Tapi Cerewet di Medsos. https://www.kominfo.go.id/content/detail/10862/teknologi-masyarakatindonesia-malas-baca-tapi-cerewet-di-medsos/0/sorotan_media (diakses tanggal 6 Desember 2020).

Fatmawati, Endang. (2017). Dampak Media Sosial Terhadap Perpustakan. Libraria, 5 (1), 1-28.

Gunawan, Arief. (2017). Pemanfaatan Media Sosial di Perpustakaan. Jurnal Pari, 3 (1), 49-52.

Hariyah \& Agus Triyanto. (2018). Media Sosial Alat Promosi Perpustakaan Badan Litbang dan Diklat Kementerian Agama RI. Jurnal Ilmu Komunikasi, 25 (2), 3241.

Jiyanto \& Muhammad Miftah. (2017). Pemanfaatan Media Sosial pada Perpustakaan Kota Literasi. Libraria, 5 (1), 199-225.

Kurniasih, Nuning. (2016). Optimalisasi Penggunaan Media Sosial untuk Perpustakaan. Prosiding Makalah Seminar Nasional "Komunikasi, Informasi dan Perpustakaan di Era Global”, Jatinangor: 15 Juni 2016. 1-10.

Mulawarman \& Aldila Dyas Nurfitri. (2017). Perilaku pengguna Media Sosial beserta Implikasinya Ditinjau dari Perspektif Psikologi Sosial Terapan. Buletin Psikologi, 25 (1), 36-44. 
Riyanto, Andi Dwi. (2018). Hootsuite (We Are Social): Indonesian Digital Report 2020. https://andi.link/hootsuite-we-are-social-indonesian-digital-report-2020/ (diakses tanggal 6 Desember 2020).

Rustiana. (2018). Persepsi Digital Dependent terhadap Pemanfaatan Media Sosial dan Dampak Sosial Ekonominya. Jurnal Ilmu Komunikasi, 15 (1), 17-32.

Santoso, Jody. (2019). Media Sosial dan Promosi Layanan Perpustakaan. 1-9.

Supriyatno, Hary. (2019). Strategi Pemanfaatan Media Sosial sebagai Sarana Promosi Perpustakaan: Studi Analisis Persepsi Pemustaka Tentang Efektifitas Pemanfaatan Media Sosial sebagai Sarana Promosi Layanan Perpustakaan UIN Sunan Ampel. Indonesian Journal of Academic Librarianship, 3 (3), 33-45.

Yenianti, Ifonilla. (2019). Promosi Perpustakaan Melalui Media Sosial di Perpustakaan IAIN Salatiga. Pustabiblia, 3 (2), 223-237. 